\title{
PROPOSING A NEW HIERARCHICAL FRAMEWORK FOR THE EVALUATION OF QUALITY MANAGEMENT PRACTICES: A NEW COMBINED FUZZY HYBRID MCDM APPROACH
}

\author{
Abbas MARDANI ${ }^{1}$, Ahmad JUSOH ${ }^{2}$, Edmundas Kazimieras ZAVADSKAS ${ }^{3}$, \\ Norhayati ZAKUAN ${ }^{4}$, Alireza VALIPOUR ${ }^{5}$, Mansooreh KAZEMILARI ${ }^{6}$ \\ ${ }^{1,2}$ Faculty of Management, Universiti Teknologi Malaysia (UTM), \\ Skudai, Johor 81300, Malaysia \\ ${ }^{3}$ Department of Construction Technology and Management, Vilnius Gediminas Technical \\ University, Sauletekio al. 11, LT-10223 Vilnius, Lithuania \\ ${ }^{4}$ Faculty of Management, Universiti Teknologi Malaysia (UTM), \\ Skudai, Johor 81310, Malaysia \\ ${ }^{5}$ Project management center (RESA group), Universiti Teknologi Malaysia, \\ Skudai, Johor 81300, Malaysia \\ ${ }^{6}$ Department of Mathematical Sciences, Faculty of Science, \\ Universiti Teknologi Malaysia (UTM), Skudai Johor, 81300, Malaysia \\ E-mails: ${ }^{2}$ mabbas3@live.utm.my (correspondingauthor); ${ }^{2}$ ahmadj@management.utm.my; \\ ${ }^{3}$ edmundas.zavadskas@vgtu.lt; ${ }^{4}$ norhayatimz@utm.my; ${ }^{5}$ valipour1802@gmail.com; \\ ${ }^{6}$ kmansooreh2@live.utm.my
}

Received 07 February 2015; accepted 09 June 2015

\begin{abstract}
This study aims to evaluate the quality management (QM) practices in Iranian hotels that are small and medium enterprises (SMEs) through the integration of the fuzzy set theory with both qualitative and quantitative methods. The criteria were collected through the literature survey and the fuzzy Delphi method (FDM). This study applied fuzzy multiple criteria decision making (FMCDM), including the fuzzy analytic hierarchy process (FAHP), the Technique for Order of Preference by Similarity to Ideal Solution (TOPSIS) and Vise Kriterijumska Optimizacija I Kompromisno Resenje (VIKOR). In the FDM phase, 21 practice was selected and categorized into four main factors. Results of the study indicated that the quality assurance was ranked as the highest important factor. From the practical viewpoint, this paper proposed new integrated model that applied FDM, FAHP, TOPSIS and VIKOR for the evaluation of QM practices in the hotel industry and introduced the environmental perspective as a new viewpoint of QM systems, especially in hotels as SMEs. In addition, the proposed model highlights a new insight into MCDM and contributes to the present body of knowledge in the area of QM systems.
\end{abstract}

Keywords: SME's hotels, quality management, fuzzy Delphi method, fuzzy FAHP, fuzzy MCDM, VIKOR, TOPSIS.

\section{JEL Classification: M2.}




\section{Introduction}

Organizational studies encompass the study of organizations from multiple perspectives and issues. Studies that focus on explanatory factors of organization performance always emphasize the contingency theory (Lawrence, Lorsch 1967) to clarify the association between the management practices, external environment, organisational characteristics and performance. The significant findings in the previous researches suggested that in order an organisational to perform well, the characteristics of the organization and the contextual factor must be considered and aligned. This is basically in line with the concept of fit (Drazin, Van de Ven 1985) that rationalize the association or relationship between explanatory variables and performance. In addition to that, effective or outstanding organisations not only have a proper match with the environment but also between its subsystems (Nadler, Tushman 1980). Scott (2003) noted that contingency theory and its principles remain the most widely utilized theoretical approach to the study of organisations. Earlier researchers, e.g. Ozturkoglu and Turker (2013), emphasized the important role of the business environment in the recent years. According to the contingency theory, the stable external environment provides opportunities and challenges for implementing the quality management (QM) (Molina-Azorín et al. 2009). It is believed that environmental issues could be considered an important perspective in quality management systems. Thus, the current study introduces the external environment as a new viewpoint to the foundation of quality management systems. Additionally, this paper attempts to provide the comprehensive list of QM systems based on a literature review. Looking from different viewpoint, QM system practices can be classified to four difference perspective i.e. environmental perspective, technological perspective, organisational perspective and people perspective. In view of that, the current study can be considered the first that introduces a comprehensive list of QM systems from four different perspectives on the hospitality industry.

In tourism industry, $\mathrm{QM}$ has been identified as a key issue to differentiate service products and building competitive advantages (Lin 2007). The majority of current studies in the hotel and hospitality industry have investigated the role of QM by presenting various practices. However, there is a lack of comprehensive information about the hotel and hospitality industry, and especially hotels in the category of SMEs. Having in mind the importance of the QM issue, it is important to note that there is no comprehensive list of QM practices. Therefore, the current study provides a comprehensive list of QM practices based on the hospitality literature. Although previous researches effort on the topic of the QM and hospitality industry examined different sets of QM practices, there is still a lack in previous studies that did not categorize the QM practices in different aspects. This particular paper focuses on the situation and needs of the hospitality industry once developing the list. However, most of the researchers focused on practices for successful QM programs, which can be traced in the developed countries, but few studies were conducted in the developing countries (Salaheldin 2009). Although QM is widely used in different industries of Iran ( $\operatorname{Rad} 2005)$, there is little evidence about improving the overall quality of specific industries, such as tourism and hospitality, as each industry has different features. The current study presents a review of the literature 
on QM and attempts to identify, evaluate and prioritize numerous quality management practices used in Iranian hotels that are SMEs. The exact objective of the current study is to elaborate on qualitative and quantitative methods in terms of linguistics used by the Fuzzy AHP (FAHP) and Fuzzy Delphi Method (FDM). In the preceding phase, two kinds of MCDM tools were applied by researchers: VIKOR and TOPSIS were used to rate and improve the operations of the hotels for identifying the best solutions. These tools were used as both VIKOR and TOPSIS are comparatively close to the ideal solution. By combining the mentioned practices, it is possible to set practices used for QM implementation that would be more appropriate for the hotel and hospitality industry.

\section{Research method and framework}

The analytical structure of this study is presented in Figure 1. In order to select the QM practices, a literature survey was made to find the primary practices for evaluation of QM practices. Two fuzzy questionnaires were provided for the current study. In the first phase, the questionnaire was formed using 43 QM practices collected from the literature. In the second phase, the questionnaire was distributed among QM specialists for their evaluation, suggestions and views. In the subsequent phase, the FAHP approach was applied to calculate the relative weight of the QM practices in three hotels located in Arak Province (Iran), namely Zagros Hotel, Amirkabir Hotel and Kaveh Hotel. This study focused on examining hotels that are SMEs and have no more than 150 employees. These hotels are rated by four and five stars and are certified by an international quality standard, such as UNE 18001, which is associated with hotel quality and ISO 9000 standard. In the last phase, the authors used two types of MCDM tools, VIKOR and TOPSIS, to rate and improve the operations of the hotels and to identify the best options. Figure 1 presents the procedure through which the framework of QM practices was developed.

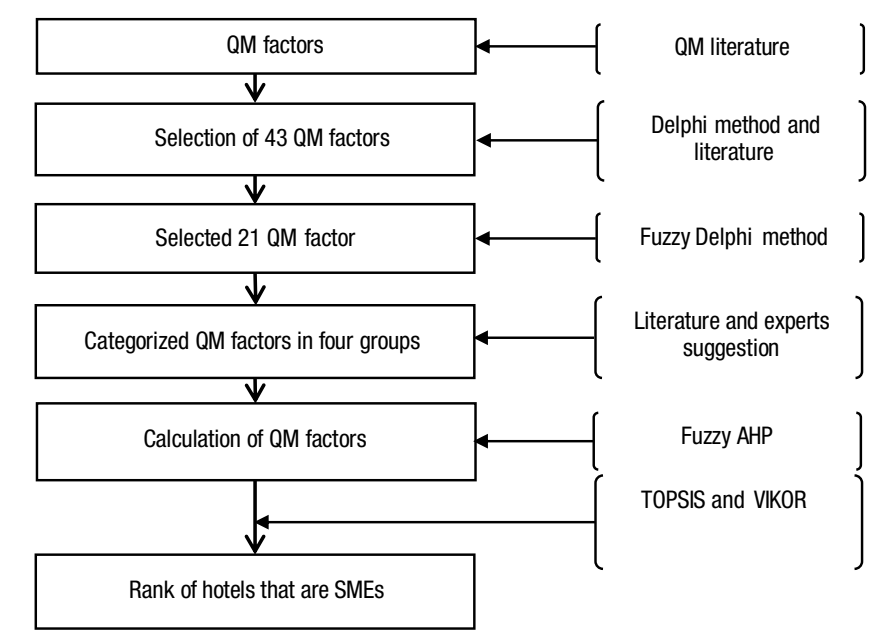

Fig. 1. Development of the framework of quality management practices 


\section{Ranking of hotels - SMEs}

To achieve the goal of the current study, three hotels were selected that fall within the category of SMEs: Zagros Hotel, Amirkabir Hotel and Kaveh Hotel. The hotels were evaluated by experts in terms of the QM success. Due to differences that exist among the viewpoints of the experts, various opinions of different managers and experts were combined to achieve a comprehensive and objective evaluation. The authors employed nine linguistic variables for the evaluation of the QM success based on the evaluation criteria. Then, fuzzy synthetic assessment of the three hotels was collected from the weights of fuzzy criteria that are provided in Table 2, and the fuzzy judgment values that are demonstrated in Table 3. Consequently, based on FAHP, the present study used two MCDM analytical tools, TOPSIS and VIKOR, in order to rank the QM success of the hotels. Based on the data presented in Table 2, the BNP values were integrated to average fuzzy judgments of different experts.

\section{Results}

\subsection{Evaluation of QM practices and the criteria framework}

The most important practices for the evaluation of QM practices were extracted during the literature survey. 43 practices were extracted from previous studies. Subsequent to FDM calculation, 21 practices were selected by the experts and classified into four different practices, namely: people practices, organisational practices, environmental practices and technological practices. According to the classification performed by the experts, the external environmental practices are composed of five practices $\left(\mathrm{C}_{11}-\mathrm{C}_{15}\right)$ : market focus, external cooperation, social and environmental responsibility, communication and suppliers. The technological practices consist of five practices $\left(\mathrm{C}_{21}-\mathrm{C}_{25}\right)$ : quality assurance, ISO 9001, benchmarking, housekeeping and quality function deployment $(Q F D)$. The people practices include five practices $\left(\mathrm{C}_{31}-\mathrm{C}_{35}\right)$ : leadership, employee involvement, employee fulfilment, employee empowerment, and customer focus. Organisational practices consist of six practices $\left(\mathrm{C}_{41}-\mathrm{C}_{46}\right)$ : process management, organisational trust, organisational culture, team working, strategic planning and continuous improvement. The hierarchical framework of this classification is presented in Figure 2.

In the next step, a fuzzy questionnaire was formed using 43 practices and sent to the experts. The experts were asked to select and categorize the most important QM practices in the Iranian hotels-SMEs. Using FDM calculation, 21 practices were selected. According to the literature on QM system and suggestions given by the experts, the 21 practices were classified into four main practices: people, organisational, environmental, and technological (Fig. 2).

\subsection{Fuzzy Delphi method}

The analytic structure of this study is presented in Figure 1. In this paper, the fuzzy set theory together with qualitative and quantitative approach are combined for the evaluation of QM practices in order to select the QM system for three hotels-SMEs. Initially, a literature survey was made to find the primary practices for evaluating the 


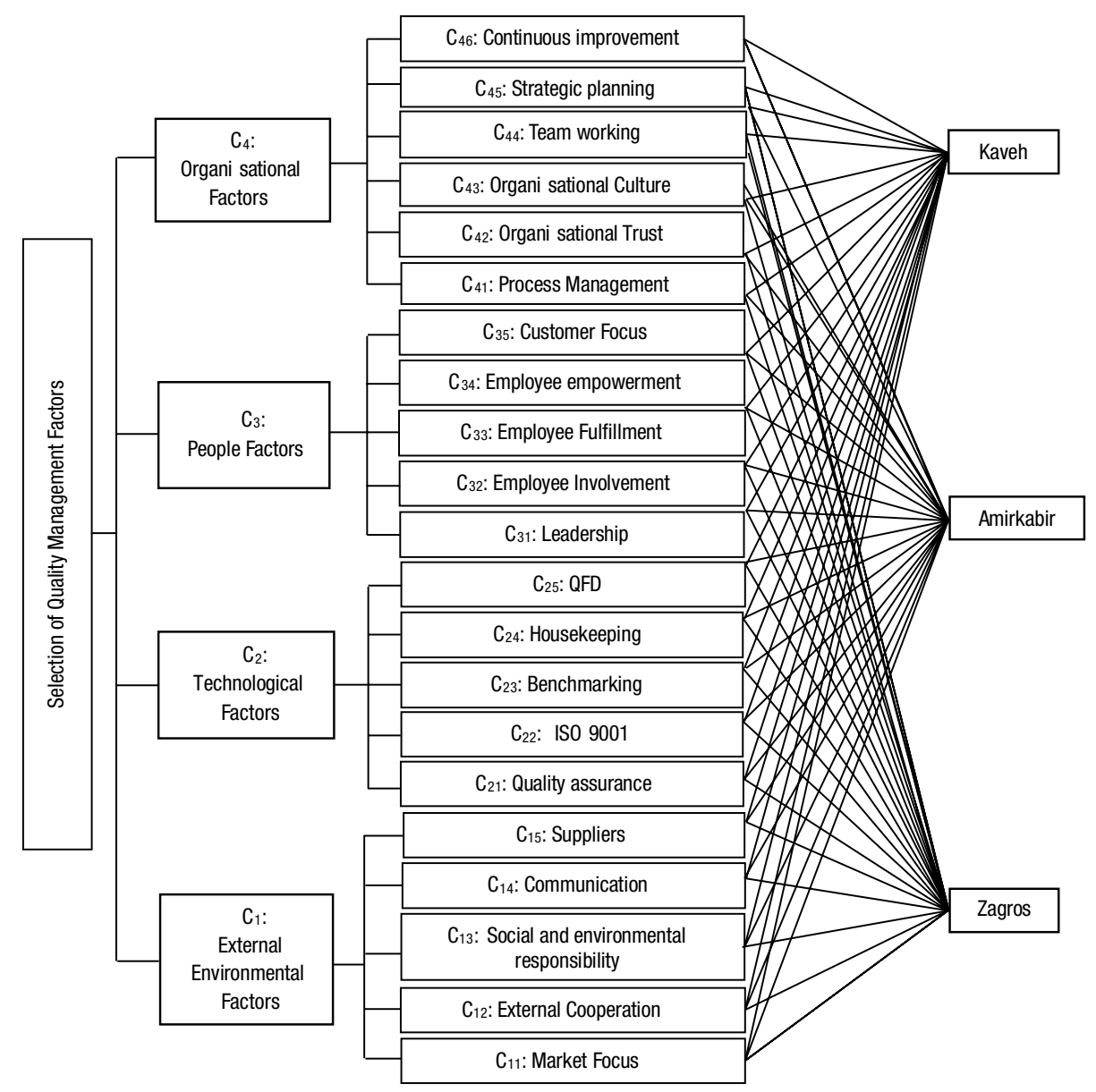

Fig. 2. Practices and sub-practices of Iranian hotels-SMEs based on FDM

QM practices. Two fuzzy questionnaires were provided for this study. In the first phase, the questionnaire was formed using 43 QM practices collected from the literature. In the second phase, the questionnaire was distributed among some QM system experts for evaluation, suggestions and opinions, which were later taken into account. The use of expert questionnaires is a useful tool for gathering required data in a Delphi survey, in cases when interviews cannot be held due to time and distance limitations (Dalkey, Helmer 1963). The questions were extracted from literature, and some of them were suggested by the experts in an open-ended format. Group size affects the efficiency of group decision-making; according to Anderson et al. (2001), 5-20 experts should participate in the validation. Accordingly, the size of decision-making group should not be too large, it should be roughly 5-50 (Gumus 2009). In the present study, 50 experts were invited to participate, from which 48 were selected, including 39 industry experts and nine academic experts in the field of QM. Finally, 45 experts participated in the research. The evaluation procedure comprised several steps: online survey questionnaires 
were used to collect the expert information. In total, 45 questionnaires were returned and validated successfully. After calculating the FDM, 21 practices were selected. According to the literature and suggestions of experts, the 21 practices were categorized in four different practices (people, organisational, environmental and technological).

Table 1. Result of fuzzy Delphi calculation of QM practices

\begin{tabular}{|c|c|c|c|c|c|}
\hline \multirow[b]{2}{*}{ QM practices } & \multicolumn{2}{|c|}{ Fuzzy calculation } & \multirow[b]{2}{*}{ QM practices } & \multicolumn{2}{|c|}{ Fuzzy calculation } \\
\hline & $\begin{array}{l}\text { Fuzzy numbers } \\
\qquad(1, \mathrm{~m}, \mathrm{u})\end{array}$ & $\begin{array}{l}\text { Defuzzi- } \\
\text { fication }\end{array}$ & & $\begin{array}{l}\text { Fuzzy numbers } \\
\qquad(1, \mathrm{~m}, \mathrm{u})\end{array}$ & $\begin{array}{l}\text { Defuzzi- } \\
\text { fication }\end{array}$ \\
\hline $\begin{array}{l}\text { Quality function } \\
\text { deployment } \\
\text { (Psychogios et al. } \\
\text { 2009) }\end{array}$ & $(0.40,0.73,1)$ & 0.71 & $\begin{array}{l}\text { Organisational } \\
\text { communication } \\
\text { (Vähätiitto 2010) }\end{array}$ & $(0.40,0.73,1)$ & 0.71 \\
\hline $\begin{array}{l}\text { Strategic management } \\
\text { (Talib et al. 2011a) }\end{array}$ & $(0.20,0.63,1)$ & $0.61 *$ & $\begin{array}{l}\text { Education } \\
\text { and training } \\
\text { (Gotzamani et al. } \\
\text { 2010) }\end{array}$ & $(0.60,0.81,1)$ & 0.80 \\
\hline $\begin{array}{l}\text { Information and } \\
\text { analysis (Sadikoglu, } \\
\text { Zehir 2010) }\end{array}$ & $(0.20,0.63,1)$ & $0.61 *$ & $\begin{array}{l}\text { Organisational } \\
\text { culture (Breiter, } \\
\text { Bloomquist 1998) }\end{array}$ & $(0.40,0.67,1)$ & $0.69 *$ \\
\hline $\begin{array}{l}\text { Matrix diagram } \\
\text { (Psychogios et al. } \\
\text { 2009) }\end{array}$ & $(0.20,0.69,1)$ & $0.63 *$ & $\begin{array}{l}\text { Employee } \\
\text { fulfilment (Wang } \\
\text { et al. 2012) }\end{array}$ & $(0.40,0.72,1)$ & 0.71 \\
\hline $\begin{array}{l}\text { Quality circles } \\
\text { (Martínez-Costa, } \\
\text { Martínez-Lorente } \\
\text { 2008) }\end{array}$ & $(0.40,0.67,1)$ & $0.69 *$ & $\begin{array}{l}\text { Learning } \\
\text { (Albacete-Sáez } \\
\text { et al. 2011) }\end{array}$ & $(0.20,0.61,1)$ & $0.60 *$ \\
\hline $\begin{array}{l}\text { Market focus } \\
\text { (Nair 2006) }\end{array}$ & $(0.40,0.69,1)$ & 0.70 & $\begin{array}{l}\text { Quality systems } \\
\text { (Allison, Byron } \\
\text { 1996) }\end{array}$ & $(0.40,0.64,1)$ & $0.68 *$ \\
\hline $\begin{array}{l}\text { Total preventive } \\
\text { maintenance } \\
\text { (Martinez-Costa, } \\
\text { Jimenez-Jimenez } \\
\text { 2008) }\end{array}$ & $(0.40,0.64,1)$ & $0.68 *$ & $\begin{array}{l}\text { Quality assurance } \\
\text { (Nair 2006) }\end{array}$ & $(0.40,0.77,1)$ & 0.72 \\
\hline $\begin{array}{l}\text { Social and } \\
\text { environmental } \\
\text { responsibility } \\
\text { (Hietschold } \\
\text { et al. 2014) }\end{array}$ & $(0.40,0.79,1)$ & 0.73 & $\begin{array}{l}\text { Quality } \\
\text { information } \\
\text { (Sila, } \\
\text { Ebrahimpour } \\
\text { 2003) }\end{array}$ & $(0.20,0.64,1)$ & $0.61 *$ \\
\hline $\begin{array}{l}\text { Just in time } \\
\text { (Robinson and } \\
\text { Malhotra 2005) }\end{array}$ & $(0.40,0.67,1)$ & $0.69 *$ & $\begin{array}{l}\text { Housekeeping } \\
\text { (Breiter, Kline } \\
\text { 1995) }\end{array}$ & $(0.40,0.79,1)$ & 0.73 \\
\hline $\begin{array}{l}\text { Suppliers (Foster Jr. } \\
\text { 2008) }\end{array}$ & $(0.40,0.73,1)$ & 0.71 & $\begin{array}{l}\text { Benchmarking } \\
\text { (Breiter, Kline } \\
\text { 1995) }\end{array}$ & $(0.40,0.75,1)$ & 0.72 \\
\hline
\end{tabular}


End of Table 1

\begin{tabular}{|c|c|c|c|c|c|}
\hline \multirow[b]{2}{*}{ QM practices } & \multicolumn{2}{|c|}{ Fuzzy calculation } & \multirow[b]{2}{*}{ QM practices } & \multicolumn{2}{|c|}{ Fuzzy calculation } \\
\hline & $\begin{array}{l}\text { Fuzzy numbers } \\
\qquad(1, \mathrm{~m}, \mathrm{u})\end{array}$ & $\begin{array}{l}\text { Defuzzi- } \\
\text { fication }\end{array}$ & & $\begin{array}{l}\text { Fuzzy numbers } \\
\qquad(1, \mathrm{~m}, \mathrm{u})\end{array}$ & $\begin{array}{l}\text { Defuzzi- } \\
\text { fication }\end{array}$ \\
\hline $\begin{array}{l}\text { Internal/external } \\
\text { cooperation (Wang } \\
\text { et al. 2012) }\end{array}$ & $(0.40,0.76,1)$ & 0.72 & $\begin{array}{l}\text { Product/service } \\
\text { design (Sila, } \\
\text { Ebrahimpour } \\
\text { 2003) }\end{array}$ & $(0.20,0.63,1)$ & $0.61 *$ \\
\hline $\begin{array}{l}\text { Quality control } \\
\text { (Breiter, Kline 1995) }\end{array}$ & $(0.20,0.68,1)$ & $0.63 *$ & $\begin{array}{l}\text { ISO } 9000 \text { series } \\
\text { (Benner, Veloso } \\
2008 \text { ) }\end{array}$ & $(0.40,0.72,1)$ & 0.71 \\
\hline $\begin{array}{l}\text { Planning for quality } \\
\text { (Claver-Cortés et al. } \\
\text { 2008) }\end{array}$ & $(0.40,0.64,1)$ & $0.68 *$ & $\begin{array}{l}\text { Strategic planning } \\
\text { (Sadikoglu, } \\
\text { Zehir 2010) }\end{array}$ & $(0.40,0.75,1)$ & 0.72 \\
\hline $\begin{array}{l}\text { Leadership (Pereira- } \\
\text { Moliner et al. 2012) }\end{array}$ & $(0.60,0.81,1)$ & 0.80 & $\begin{array}{l}\text { Employee } \\
\text { involvement } \\
\text { (Pereira-Moliner } \\
\text { et al. 2012) }\end{array}$ & $(0.40,0.72,1)$ & 0.71 \\
\hline $\begin{array}{l}\text { Inspection practices } \\
\text { (Robinson, Malhotra } \\
\text { 2005) }\end{array}$ & $(0.20,0.69,1)$ & $0.63 *$ & $\begin{array}{l}\text { Process } \\
\text { management } \\
\text { (Pereira-Moliner } \\
\text { et al. 2012) }\end{array}$ & $(0.40,0.73,1)$ & 0.71 \\
\hline $\begin{array}{l}\text { Organisational trust } \\
\text { (Kull, Wacker 2010) }\end{array}$ & $(0.40,0.73,1)$ & 0.71 & $\begin{array}{l}\text { Continuous } \\
\text { improvement } \\
\text { (Wang et al. 2012) }\end{array}$ & $(0.40,0.73,1)$ & 0.71 \\
\hline $\begin{array}{l}\text { Flow chart (Martinez- } \\
\text { Costa, Jimenez- } \\
\text { Jimenez 2008) }\end{array}$ & $(0,0.63,1)$ & $0.54 *$ & $\begin{array}{l}\text { Organisational } \\
\text { culture (Breiter, } \\
\text { Bloomquist 1998) }\end{array}$ & $(0.40,0.76,1)$ & 0.72 \\
\hline $\begin{array}{l}\text { Problem solving } \\
\text { methodology } \\
\text { (Phan et al. 2011) }\end{array}$ & $(0.20,0.74,1)$ & $0.65 *$ & $\begin{array}{l}\text { Design process } \\
\text { management (Sila, } \\
\text { Ebrahimpour } \\
\text { 2003) }\end{array}$ & $(0.20,0.69,1)$ & $0.63 *$ \\
\hline $\begin{array}{l}\text { Histograms } \\
\text { (Psychogios et al. } \\
\text { 2009) }\end{array}$ & $(0.20,0.67,1)$ & $0.62 *$ & $\begin{array}{l}\text { Reward appraisals } \\
\text { systems } \\
\text { (Robinson, } \\
\text { Malhotra 2005) }\end{array}$ & $(0.20,0.67,1)$ & $0.62 *$ \\
\hline $\begin{array}{l}\text { Competent staff } \\
\text { (Ali et al. 2010) }\end{array}$ & $(0.20,0.68,1)$ & $0.63 *$ & $\begin{array}{l}\text { FMEA (Robinson, } \\
\text { Malhotra 2005) }\end{array}$ & $(0.20,0.61,1)$ & $0.60 *$ \\
\hline $\begin{array}{l}\text { Customer focus } \\
\text { (Wang et al. 2012) }\end{array}$ & $(0.40,0.75,1)$ & 0.72 & $\begin{array}{l}\text { Team working } \\
\text { (Alvarez et al. } \\
\text { 2012) }\end{array}$ & $(0.40,0.72,1)$ & 0.71 \\
\hline $\begin{array}{l}\text { Pareto diagrams } \\
\text { (Martínez-Costa, } \\
\text { Martínez-Lorente } \\
\text { 2008) }\end{array}$ & $(0.20,0.56,1)$ & $0.59 *$ & & & \\
\hline
\end{tabular}


From the FDM steps, the calculated result was obtained as presented in Table 1. Eliminating 22 less important indicators from the total of initial 43 QM practices, it reduced to the total of 21 indicators. According to the literature, discussions held with the experts, and expert suggestions, 21 practices were categorized into four main practices, people, environmental, organisational, and technological. Figure 2 represents these categories based on the practices and sub-practices for Iranian hotels, which could be also used to determine the criteria weights of the FAHP method.

\subsection{Fuzzy AHP}

In the third step, the FAHP approach was used to calculate the relative weight of the QM practices in the three hotels. Regarding the ranking procedure, the most significant QM practices in the three Iranian hotels were selected based on the hierarchical framework introduced in the first stage of this research. The practices were included in the FAHP questionnaire and distributed among the experts of QM hotels-SMEs in order to receive suggestions and opinions. This questionnaire was designed based on the Triangular Fuzzy Numbers (TNF). Tables 2 and 3 show the fuzzy weight and the fuzzy judgment values of QM practices by FAHP.

Table 2. Fuzzy weight of QM practices by FAHP

\begin{tabular}{cccccc}
\hline $\begin{array}{c}\text { Criteria (dimension } \\
\text { and index) }\end{array}$ & Local weights & Overall weights & BNP* & $\begin{array}{c}\text { Standart } \\
\text { BNP** }\end{array}$ & Rank \\
\hline $\mathbf{C}_{\mathbf{1}}$ & $\mathbf{( 0 . 0 9 5 , 0 . 1 3 9 , 0 . 2 0 2 )}$ & & $\mathbf{0 . 1 5}$ & $\mathbf{0 . 1 9}$ & $\mathbf{4}$ \\
\hline $\mathrm{C}_{11}$ & $(0.135,0.198,0.291)$ & $(0.011,0.022,0.046)$ & 0.21 & 0.03 & 21 \\
\hline $\mathrm{C}_{12}$ & $(0.134,0.192,0.274)$ & $(0.018,0.037,0.075)$ & 0.20 & 0.04 & 12 \\
\hline $\mathrm{C}_{13}$ & $(0.166,0.226,0.325)$ & $(0.016,0.031,0.066)$ & 0.24 & 0.04 & 13 \\
\hline $\mathrm{C}_{14}$ & $(0.166,0.226,0.325)$ & $(0.015,0.031,0.060)$ & 0.23 & 0.04 & 16 \\
\hline $\mathrm{C}_{15}$ & $(0.164,0.222,0.310)$ & $(0.016,0.031,0.066)$ & 0.235 & 0.04 & 14 \\
\hline $\mathbf{C}_{\mathbf{2}}$ & $\mathbf{( 0 . 1 6 4 , 0 . 2 3 2 , 0 . 3 2 7 )}$ & & $\mathbf{0 . 2 4}$ & $\mathbf{0 . 3 2}$ & $\mathbf{1}$ \\
\hline $\mathrm{C}_{21}$ & $(0.289,0.392,0.537)$ & $(0.048,0.091,0.176)$ & 0.41 & 0.11 & 1 \\
\hline $\mathrm{C}_{22}$ & $(0.202,0.278,0.376)$ & $(0.033,0.065,0.123)$ & 0.29 & 0.07 & 5 \\
\hline $\mathrm{C}_{23}$ & $(0.158,0.230,0.327)$ & $(0.022,0.044,0.089)$ & 0.24 & 0.05 & 8 \\
\hline $\mathrm{C}_{24}$ & $(0.261,0.355,0.483)$ & $(0.034,0.067,0.132)$ & 0.37 & 0.08 & 3 \\
\hline $\mathrm{C}_{25}$ & $(0.191,0.274,0.373)$ & $(0.018,0.038,0.075)$ & 0.28 & 0.04 & 11 \\
\hline $\mathbf{C}_{\mathbf{3}}$ & $(\mathbf{0 . 0 1 0 , 0 . 1 3 6 , 0 . 1 9 8 )}$ & & $\mathbf{0 . 1 8}$ & $\mathbf{0 . 2 3}$ & $\mathbf{3}$ \\
\hline $\mathrm{C}_{31}$ & $(0.200,0.279,0.379)$ & $(0.019,0.039,0.076)$ & 0.29 & 0.05 & 10 \\
\hline $\mathrm{C}_{32}$ & $(0.168,0.246,0.354)$ & $(0.013,0.028,0.056)$ & 0.26 & 0.03 & 17 \\
\hline $\mathrm{C}_{33}$ & $(0.136,0.190,0.267)$ & $(0.013,0.026,0.051)$ & 0.20 & 0.03 & 18 \\
\hline $\mathrm{C}_{34}$ & $(0.150,0.217,0.304)$ & $(0.012,0.024,0.048)$ & 0.22 & 0.03 & 19 \\
\hline $\mathrm{C}_{35}$ & $(0.089,0.126,0.174)$ & $(0.012,0.024,0.047)$ & 0.13 & 0.03 & 20 \\
\hline & & & & & \\
\hline
\end{tabular}


End of Table 2

\begin{tabular}{cccccc}
\hline $\begin{array}{c}\text { Criteria (dimension } \\
\text { and index) }\end{array}$ & Local weights & Overall weights & BNP* & $\begin{array}{c}\text { Standart } \\
\text { BNP** }\end{array}$ & Rank \\
\hline $\mathbf{C}_{4}$ & $\mathbf{( 0 . 1 3 7 , 0 . 1 9 2 , 0 . 2 7 3 )}$ & & $\mathbf{0 . 2 0}$ & $\mathbf{0 . 2 6}$ & $\mathbf{2}$ \\
\hline $\mathrm{C}_{41}$ & $(0.211,0.293,0.411)$ & $(0.029,0.056,0.112)$ & 0.31 & 0.07 & 7 \\
\hline $\mathrm{C}_{42}$ & $(0.164,0.222,0.310)$ & $(0.029,0.056,0.112)$ & 0.23 & 0.04 & 15 \\
\hline $\mathrm{C}_{43}$ & $(0.229,0.330,0.475)$ & $(0.038,0.077,0.155)$ & 0.35 & 0.09 & 2 \\
\hline $\mathrm{C}_{44}$ & $(0.235,0.333,0.471)$ & $(0.030,0.063,0.129)$ & 0.35 & 0.07 & 4 \\
\hline $\mathrm{C}_{45}$ & $(0.210,0.308,0.437)$ & $(0.020,0.042,0.083)$ & 0.32 & 0.05 & 9 \\
\hline $\mathrm{C}_{46}$ & $(0.229,0.312,0.424)$ & $(0.030,0.063,0.129)$ & 0.32 & 0.07 & 6 \\
\hline
\end{tabular}

Table 3. Weights of hotel indexes according to FAHP

\begin{tabular}{cccc}
\hline Indexes & Amirkabir & Zagros & Kaveh \\
\hline $\mathrm{C}_{11}$ & 0.57 & 0.54 & 0.61 \\
\hline $\mathrm{C}_{12}$ & 0.58 & 0.48 & 0.65 \\
\hline $\mathrm{C}_{13}$ & 0.52 & 0.58 & 0.63 \\
\hline $\mathrm{C}_{14}$ & 0.45 & 0.66 & 0.60 \\
\hline $\mathrm{C}_{11}$ & 0.61 & 0.53 & 0.59 \\
\hline $\mathrm{C}_{21}$ & 0.55 & 0.56 & 0.62 \\
\hline $\mathrm{C}_{22}$ & 0.55 & 0.60 & 0.58 \\
\hline $\mathrm{C}_{23}$ & 0.57 & 0.63 & 0.52 \\
\hline $\mathrm{C}_{24}$ & 0.56 & 0.53 & 0.63 \\
\hline $\mathrm{C}_{25}$ & 0.53 & 0.50 & 0.69 \\
\hline $\mathrm{C}_{31}$ & 0.57 & 0.52 & 0.63 \\
\hline $\mathrm{C}_{32}$ & 0.56 & 0.57 & 0.60 \\
\hline $\mathrm{C}_{33}$ & 0.60 & 0.57 & 0.57 \\
\hline $\mathrm{C}_{34}$ & 0.50 & 0.63 & 0.60 \\
\hline $\mathrm{C}_{35}$ & 0.57 & 0.60 & 0.45 \\
\hline $\mathrm{C}_{41}$ & 0.54 & 0.57 & 0.63 \\
\hline $\mathrm{C}_{42}$ & 0.47 & 0.66 & 0.58 \\
\hline $\mathrm{C}_{43}$ & 0.52 & 0.65 & 0.54 \\
\hline $\mathrm{C}_{44}$ & 0.56 & 0.42 & 0.60 \\
\hline $\mathrm{C}_{45}$ & 0.62 & 0.52 & \\
\hline $\mathrm{C}_{46}$ & 0.49 & 0.75 & \\
\hline & & & 0.58 \\
\hline
\end{tabular}




\subsection{Validation procedure}

In order to test the validity of the proposed model and verify the obtained results, the direct results of prioritized three hotels from TOPSIS were compared to those received by other methods, including VIKOR. Table 4 gives a summary of the final values and preference order ranking by two MCDM methods (VIKOR and TOPSIS), which relate to the ranking outcomes by VIKOR and TOPSIS. While the standardized rate in the VIKOR technique does not relate to the assessment part of a criterion function, the vector normalization rate in the TOPSIS technique might be related to the assessment part. Based on the outcomes, VIKOR and TOPSIS were identical; however, VIKOR represents a good technique for evaluation. The results of Table 4 indicate that ranking of three hotels had similar rank by two methods. Therefore, the validity of the model is seen. Moreover, results of ranking the three hotels and validity of the two methods are graphically represented in Figure 3.

Table 4. Summary of the final preference order ranking by VIKOR and TOPSIS

\begin{tabular}{ccc}
\hline VIKOR & TOPSIS & Hotels \\
\hline $0.38(1)$ & $0.6005(1)$ & Amirkabir \\
\hline $0.42(2)$ & $0.4764(2)$ & Zagros \\
\hline $0.46(3)$ & $0.4717(3)$ & Kaveh \\
\hline
\end{tabular}

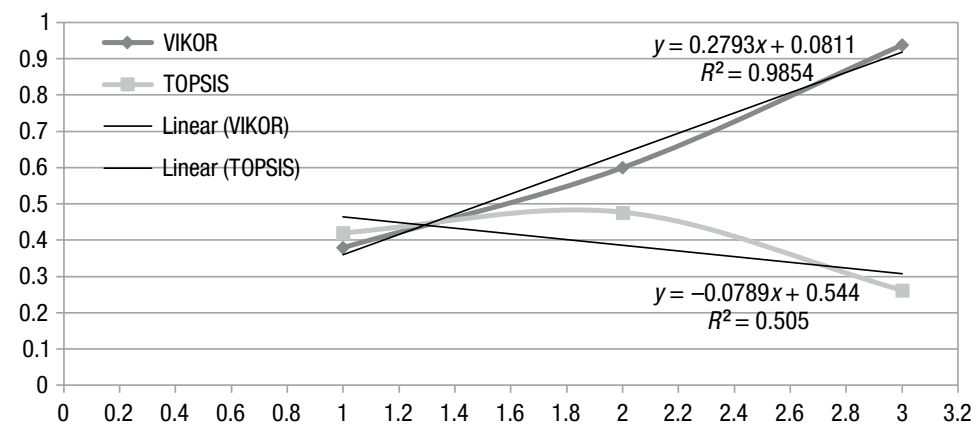

Fig. 3. Validity of two methods and results

\section{Discussion}

The findings of the FAHP step are presented in Tables 2 and 3, which show the technological practices of the QM practices that had the highest weight $(0.32)$ in comparison with other main practices, namely, the organisational practices $(0.26)$, people practices $(0.23)$ and environmental practices $(0.19)$. The results obtained in this step are supported by studies previously conducted on the QM system. With regard to the computation of FAHP, quality assurance from the technological practices was ranked as the first QM practice. This is supported by some researchers, e.g. Sun (2000). According to Sun (2000), quality assurance is one of the most significant criteria, which was ranked second (3.90) out of 14 QM criteria presented in this study. Based on this result, we can 
indicate that quality assurance should be integrated into processes of a hotel. It should also be hotel-wide to include all staff. It may be easy to integrate quality assurance in all areas of production/service; however, it is not as easy when it comes to the alignment of staff attitudes and behaviours with quality performance. Moreover, it can enable managers to evaluate the levels of quality of a certain product/service as it reaches the customer, to continuously improve the quality of the product/service.

Organisational culture was ranked as the second important factor among organisational practices. In a number of previously-conducted studies, e.g. Gupta et al. (2005), Kull and Wacker (2010), Naor et al. (2008), the significance of culture was confirmed. These studies argued that organisational culture is an important factor for the success of QM efforts in services organisations. Moreover, Claver et al. (2006) stated that an effective QM system can improve the image of a hotel and has a positive influence on the customer satisfaction and the quality of services. Customer focus and satisfaction had the highest coverage followed by issues related to TQM practices (Lewis et al. 2006). It was demonstrated that in the hotel industry, hotels that are TQM-committed outperform as TQM enhances customer satisfaction (Claver-Cortés et al. 2008). Wang et al. (2012) reported that TQM elements, such as customer focus (factor loading, 0.75), are considered as the most significant for hotel TQM practices. To this end, hotel managers should enhance their employee awareness regarding the changing needs of customers and market demands.

In addition, the literature shows an unquestionable consensus on the relevance of leadership and the management's commitment to achieving the success in these systems (Kaynak 2003). Indeed, the management's commitment is taken into account as a condition that must exist to attain the transformations required for QM (Talib et al. 2011b). The leadership is focused on the principles that are most commonly incorporated into TQM programs of hotels (Li et al. 2007). Thus, managers play a key role in the entire quality improvement process of a hotel. Testa and Sipe (2012) believe that leadership behaviours of hotel managers make the employee performance and satisfaction perception easy. Vrdoljak-Raguž (2007) carried out a study on the Croatia's hotel industry and found that numerous supervisors enjoyed the leadership skills such as partial authorization, giving awards, teamwork, and communication and they wanted employees to be responsible and achieve set goals.

In technological practices, although benchmarking factor has the eighth position in the ranking, these findings support a number of studies conducted by Powell (1995), Dow et al. (1999), and Samson and Terziovski (1999) in which no significant relationship was found between organisational performance and TQM elements. TQM systems and tools such as benchmarking in both five-star and four-star hotels were implemented in completely similar levels and ways.

In case of ranking the three large Araks city hotels - Zagros, Amirkabir and Kaveh which were selected for the purpose of this study, these hotels were evaluated by the panel of experts in terms of the success of the QM systems. To rank these three hotels, two kinds of DM techniques were used, including TOPSIS and VIKOR. According to 
the results presented in Table (4), the researchers concluded that Amirkabir Hotel has the first rank in case of both TOPSIS (0.6005) and VIKOR (0.38). In addition, Zagros Hotel ranked second according to both TOPSIS (0.4764) and VIKOR (0.42). Finally, Kaveh Hotel ranked third according to both TOPSIS (0.4717) and VIKOR (0.46).

This study offers a number of contributions. First, this study combined the fuzzy set theory and qualitative and quantitative approaches to evaluate the QM practices for the selection of three hotels that are SME. Second, the current study identified and presented the inclusive list of $43 \mathrm{QM}$ practices, which were extracted from previous studies, especially those conducted in the tourism and hospitality industry. Subsequent to FDM calculation, 21 practices were selected by experts and classified into four new areas, including: people practices, organisational practices, environmental practices and technological practices. Third, FAHP was employed, since a number of scholars, such as Boender et al. (1989), reported that FAHP provided more adequate descriptions of decision-making processes in comparison to the conventional AHP methods.

Finally, TOPSIS was used for rating and improving the operations of the hotels and specifying the most appropriate options. For testing the validity of the proposed model and verifying the obtained results, the direct results of prioritized three hotels from TOPSIS were compared using another method, VIKOR. The results of this validation indicated that the rank of the three hotels was similar in the case of both methods.

\section{Conclusions}

In this study, qualitative and quantitative approaches are proposed by combining a focus group, FAHP and FDM in order to develop an evaluation framework for QM practices in the hotels-SME. This study considered issues that deserve more attention in hospitality research, namely QM, especially in fast-growing countries, such as Iran. It is evident that promotion of technological QM practices and upgrading of technologies may enhance the competitive advantage. Paying adequate attention to the process, product, and information technology may improve the quality; though, in the end, people can develop the quality. On the other hand, management literature asserts that the technological QM practices have a considerable effect on the organisational performance. Comparing and measuring the business processes of an organisation against the best-in-class operations inspires the improvement in the organisational performance. Insights obtained from benchmarking provide a foundation for organisations to build operational plans in order to meet and even outperform the best practices of the industry.

In the future, several other techniques, such as fuzzy preference relations and entropy, could be used by researchers for the improvement of the process for calculation of criteria weights, which are used to evaluate QM systems. Moreover, further studies and researches are suggested to draw on the effectiveness of the proposed criteria weights for evaluation of QM practices. The current study can be of great help in the development of a framework that helps to understand the significance of QM, its implementation, identification of major QM practices and adoption of a QM programme in hotels-SMEs and the hospitality industry. Furthermore, the presented research method will serve as 
a basis for practitioners and managers for the evaluation of the company's quality level as compared to other methods presented by researchers. The findings can correspondingly set as a standard intended for the level of QM, which should apply to hotels-SME and the hospitality industry. This information can benefit the continuous improvement and expansion of hotels-SMEs and the hospitality industry. Moreover, understanding of the basic QM practices highlighted in this study will help managers to improve their knowledge and enhance the potential of traditional quality systems. In a nutshell, this research will contribute significantly to the improvement of QM practices and the issues related to the quality of the industry.

Even though the current study presented several advantages, there are some limitations as well. Firstly, based on the FDM calculation and expert opinions, some QM practices were removed, for example, in the first step, the total of initial 43 QM practices (Table 1) was reduced to the total of 21 practices (Fig. 2); therefore, the final analysis of results was made based on 21 practices of QM systems. Secondly, this paper applied some DM techniques such as FDM, FAHP, F-TOPSIS and VIKOR, therefore future studies could be made and compared with other methods such as Modified TOPSIS, ANP, fuzzy ANP and PROMETHEE, etc. As another limitation of this paper, the researchers only focused on hotels-SMEs, although, the results and contribution of this paper would be useful to hotel managers of the majority hotels-SMEs around the world. Future studies may use the study methodology and framework for other service organisations.

\section{References}

Albacete-Sáez, C. A.; Fuentes-Fuentes, M. M.; Bojica, A. M. 2011. Quality management, strategic priorities and performance: the role of quality leadership, Industrial Management \& Data Systems 111(8): 1173-1193. http://dx.doi.org/10.1108/02635571111170758

Ali, N. A.; Mahat, F.; Zairi, M. 2010. Testing the criticality of HR-TQM factors in the Malaysian higher education context, Total Quality Management and Business Excellence 21(11): 1177-1188. http://dx.doi.org/10.1080/14783360701349534

Allison, J. H.; Byron, M. A. 1996. Aligning quality improvement with strategic goals at ANA Hotel San Francisco, National Productivity Review 15(2): 89-99.

http://dx.doi.org/10.1002/npr.4040150210

Alvarez, M. J.; Jaca, C.; Viles, E.; Colomer, A. 2012. Quality management in hotels in the Basque country, International Journal of Quality and Service Sciences 4(1): 51-60.

http://dx.doi.org/10.1108/17566691211219724

Anderson, T.; Liam, R.; Garrison, D. R.; Archer, W. 2001. Assessing teacher presence in a computer conferencing context, Journal of the Asynchronous Learning Network 5(2): 1-17.

Benner, M. J.; Veloso, F. M. 2008. ISO 9000 practices and financial performance: a technology coherence perspective, Journal of Operations Management 26(5): 611-629.

http://dx.doi.org/10.1016/j.jom.2007.10.005

Boender, C.; De Graan, J.; Lootsma, F. 1989. Multi-criteria decision analysis with fuzzy pairwise comparisons, Fuzzy Sets and Systems 29(2): 133-143.

http://dx.doi.org/10.1016/0165-0114(89)90187-5

Breiter, D.; Bloomquist, P. 1998. TQM in American hotels: an analysis of application, The Cornell Hotel and Restaurant Administration Quarterly 39(1): 26-33.

http://dx.doi.org/10.1177/001088049803900105 
Breiter, D.; Kline, S. F. 1995. Benchmarking quality management in hotels, Hospitality Review 13(2): 45-52.

Claver-Cortés, E.; Pereira-Moliner, J.; Tarí, J. J.; Molina-Azorín, J. F. 2008. TQM, managerial factors and performance in the Spanish hotel industry, Industrial Management \& Data Systems 108(2): 228-244. http://dx.doi.org/10.1108/02635570810847590

Claver, E.; Tarí, J. J.; Pereira, J. 2006. Does quality impact on hotel performance?, International Journal of Contemporary Hospitality Management 18(4): 350-358.

http://dx.doi.org/10.1108/09596110610665357

Dalkey, N.; Helmer, O. 1963. An experimental application of the Delphi method to the use of experts, Management Science 9(3): 458-467. http://dx.doi.org/10.1287/mnsc.9.3.458

Dow, D.; Samson, D.; Ford, S. 1999. Exploding the myth: do all quality management practices contribute to superior quality performance?, Production and Operations Management 8(1): 1-27. http://dx.doi.org/10.1111/j.1937-5956.1999.tb00058.x

Drazin, R.; Van de Ven, A. H. 1985. Alternative forms of fit in contingency theory, Administrative Science Quarterly 30(4): 514-539. http://dx.doi.org/10.2307/2392695

Foster, Jr. S. T. 2008. Towards an understanding of supply chain quality management, Journal of Operations Management 26(4): 461-467. http://dx.doi.org/10.1016/j.jom.2007.06.003

Gotzamani, K.; Longinidis, P.; Vouzas, F. 2010. The logistics services outsourcing dilemma: quality management and financial performance perspectives, Supply Chain Management: an International Journal 15(6): 438-453. http://dx.doi.org/10.1108/13598541011080428

Gumus, A. T. 2009. Evaluation of hazardous waste transportation firms by using a two step fuzzyAHP and TOPSIS methodology, Expert Systems with Applications 36(2): 4067-4074.

http://dx.doi.org/10.1016/j.eswa.2008.03.013

Gupta, A.; McDaniel, J. C.; Herath, S. K. 2005. Quality management in service firms: sustaining structures of total quality service, Managing Service Quality 15(4): 389-402.

http://dx.doi.org/10.1108/09604520510606853

Hietschold, N.; Reinhardt, R.; Gurtner, S. 2014. Measuring critical success factors of TQM implementation successfully - a systematic literature review, International Journal of Production Research 52(21): 6254-6272. http://dx.doi.org/10.1080/00207543.2014.918288

Kaynak, H. 2003. The relationship between total quality management practices and their effects on firm performance, Journal of Operations Management 21(4): 405-435.

http://dx.doi.org/10.1016/S0272-6963(03)00004-4

Kull, T. J.; Wacker, J. G. 2010. Quality management effectiveness in Asia: the influence of culture, Journal of Operations Management 28(3): 223-239. http://dx.doi.org/10.1016/j.jom.2009.11.003

Lawrence, P. R.; Lorsch, J. W. 1967. Managing differentiation and integration, in Organization and Environment. Boston, Massachusetts: Harvard University.

Lewis, W. G.; Pun, K. F.; Lalla, T. 2006. Exploring soft versus hard factors for TQM implementation in small and medium-sized enterprises, International Journal of Productivity and Performance Management 55(7): 539-554. http://dx.doi.org/10.1108/17410400610702142

Li, L.; Tse, E. C. Y.; Xie, L. 2007. Hotel general manager profile in China: a case of Guangdong Province, International Journal of Contemporary Hospitality Management 19(4): 263-274. http://dx.doi.org/10.1108/09596110710747607

Lin, W. B. 2007. An empirical of service quality model from the viewpoint of management, Expert Systems with Applications 32(2): 364-375. http://dx.doi.org/10.1016/j.eswa.2005.11.033

Martinez-Costa, M.; Jimenez-Jimenez, D. 2008. Are companies that implement TQM better learning organisations? An empirical study, Total Quality Management and Business Excellence 19(11): 1101-1115. 
Martínez-Costa, M.; Martínez-Lorente, A. R. 2008. Does quality management foster or hinder innovation? An empirical study of Spanish companies, Total Quality Management and Business Excellence 19(3): 209-221. http://dx.doi.org/10.1080/14783360802323446

Molina-Azorín, J. F.; Tarí, J. J.; Claver-Cortés, E.; López-Gamero, M. D. 2009. Quality management, environmental management and firm performance: a review of empirical studies and issues of integration, International Journal of Management Reviews 11(2): 197-222.

http://dx.doi.org/10.1111/j.1468-2370.2008.00238.x

Nadler, D. A.; Tushman, M. L. 1980. A model for diagnosing organizational behavior, Organizational Dynamics 9(2): 35-51. http://dx.doi.org/10.1016/0090-2616(80)90039-X

Nair, A. 2006. Meta-analysis of the relationship between quality management practices and firm performance - implications for quality management theory development, Journal of Operations Management 24(6): 948-975. http://dx.doi.org/10.1016/j.jom.2005.11.005

Naor, M.; Goldstein, S. M.; Linderman, K. W.; Schroeder, R. G. 2008. The role of culture as driver of quality management and performance: infrastructure versus core quality practices, Decision Sciences 39(4): 671-702. http://dx.doi.org/10.1111/j.1540-5915.2008.00208.x

Ozturkoglu, Y.; Turker, D. 2013. Application of TOPSIS to analyze stakeholder relations, International Journal of Business and Social Research 3(5): 245-255.

Pereira-Moliner, J.; Claver-Cortés, E.; Molina-Azorín, J. F.; José Tarí, J. 2012. Quality management, environmental management and firm performance: direct and mediating effects in the hotel industry, Journal of Cleaner Production 37: 82-92.

http://dx.doi.org/10.1016/j.jclepro.2012.06.010

Phan, A. C.; Abdallah, A. B.; Matsui, Y. 2011. Quality management practices and competitive performance: empirical evidence from Japanese manufacturing companies, International Journal of Production Economics 133(2): 518-529. http://dx.doi.org/10.1016/j.ijpe.2011.01.024

Powell, T. C. 1995. Total quality management as competitive advantage: a review and empirical study, Strategic Management Journal 16(1): 15-37. http://dx.doi.org/10.1002/smj.4250160105

Psychogios, A. G.; Wilkinson, A.; Szamosi, L. T. 2009. Getting to the heart of the debate: TQM and middle manager autonomy, Total Quality Management and Business Excellence 20(4): 445466. http://dx.doi.org/10.1080/14783360902781949

Rad, A. M. M. 2005. A survey of total quality management in Iran: barriers to successful implementation in health care organizations, Leadership in Health Services 18(3): 12-34.

http://dx.doi.org/10.1108/13660750510611189

Robinson, C. J.; Malhotra, M. K. 2005. Defining the concept of supply chain quality management and its relevance to academic and industrial practice, International Journal of Production Economics 96(3): 315-337. http://dx.doi.org/10.1016/j.ijpe.2004.06.055

Sadikoglu, E.; Zehir, C. 2010. Investigating the effects of innovation and employee performance on the relationship between total quality management practices and firm performance: an empirical study of Turkish firms, International Journal of Production Economics 127(1): 13-26. http://dx.doi.org/10.1016/j.ijpe.2010.02.013

Salaheldin, S. I. 2009. Critical success factors for TQM implementation and their impact on performance of SMEs, International Journal of Productivity and Performance Management 58(3): 215-237. http://dx.doi.org/10.1108/17410400910938832

Samson, D.; Terziovski, M. 1999. The relationship between total quality management practices and operational performance, Journal of Operations Management 17(4): 393-409.

http://dx.doi.org/10.1016/S0272-6963(98)00046-1

Scott, T. 2003. Health care performance and organizational culture. Radcliffe Publishing.

Sila, I.; Ebrahimpour, M. 2003. Examination and comparison of the critical factors of total quality management (TQM) across countries, International Journal of Production Research 41(2): 235-268. http://dx.doi.org/10.1080/0020754021000022212 
Sun, H. 2000. Total quality management, ISO 9000 certification and performance improvement, International Journal of Quality \& Reliability Management 17(2): 168-179. http://dx.doi.org/10.1108/02656710010304573

Talib, F.; Rahman, Z.; Qureshi, M. 2011. Prioritising the practices of total quality management: an analytic hierarchy process analysis for the service industries, Total Quality Management and Business Excellence 22(12): 1331-1351. http://dx.doi.org/10.1080/14783363.2011.625192

Talib, F.; Rahman, Z.; Qureshi, M.; Siddiqui, J. 2011. Total quality management and service quality: an exploratory study of quality management practices and barriers in service industry, International Journal of Services and Operations Management 10(1): 94-118.

Testa, M. R.; Sipe, L. 2012. Service-leadership competencies for hospitality and tourism management, International Journal of Hospitality Management 31(3): 648-658.

http://dx.doi.org/10.1016/j.ijhm.2011.08.009

Vähätiitto, J. 2010. Environmental quality management in hospitality industry - Case Hotel K5 Levi. Aalto University Library, Helsinki.

Vrdoljak-Raguž, I. 2007. The interdependence between characteristics and leadership style of managers in the hospitality industry in Dubrovnik-Neretva county: empirical research, Management: Journal of Contemporary Management Issues 12(2): 57-68.

Wang, C.-H.; Chen, K.-Y.; Chen, S.-C. 2012. Total quality management, market orientation and hotel performance: the moderating effects of external environmental factors, International Journal of Hospitality Management 31(1): 119-129. http://dx.doi.org/10.1016/j.ijhm.2011.03.013

Zavadskas, E. K.; Turskis, Z. 2011. Multiple criteria decision making (MCDM) methods in economics: an overview, Technological and Economic Development of Economy 17(2): 397-427. http://dx.doi.org/10.3846/20294913.2011.593291

Abbas MARDANI is Senior Lecturer PhD at the Faculty of Management, Universiti Teknologi Malaysia (UTM).

Ahmad JUSOH is Senior Lecturer (PhD) at the Faculty of Management, Universiti Teknologi Malaysia (UTM).

Edmundas Kazimieras ZAVADSKAS is PhD, DSc, h.c.multi. Prof., Head of the Department of Construction Technology and Management at Vilnius Gediminas Technical University, Lithuania.

Norhayati ZAKUAN is Senior Lecturer $(\mathrm{PhD})$ at the Faculty of Management, Universiti Teknologi Malaysia (UTM).

Alireza VALIPOUR is currently a $\mathrm{PhD}$ at the Faculty of Civil Engineering, Universiti Teknologi Malaysia (UTM).

Mansooreh KAZEMILARI is $\mathrm{PhD}$ at the Department of Mathematical Sciences of the Faculty of Science,Universiti Teknologi Malaysia (UTM). 